\title{
Role of Ionized Magnesium on Insulin Secretory Function and Insulin Sensitivity in Type 2 Diabetic Bangladeshi Subjects Mahfuja Rahman, ${ }^{\text {aft }}$ Mohammad Abdur Rashid, ${ }^{\text {af** }}$ Mohammed Danish Akbar, ${ }^{\mathrm{b}}$ Mahmuda Haque, Liaquat $\mathrm{Ali}^{\mathrm{a}}$ \\ ${ }^{a}$ Department of Biochemistry \& Cell Biology, Biomedical Research Group, BIRDEM, Dhaka 1000, Bangladesh; \\ ${ }^{\mathbf{b}}$ Section of Molecular Pharmacology and Toxicology, Laboratory of Membrane Biochemistry and \\ Biophysics, National Institute on Alcohol Abuse and Alcoholism, Bethesda, MD, USA. ${ }^{\mathbf{c}}$ Department of Pharmacy, Southeast University, Dhaka 1213, Bangladesh. "Equal Contribution, *Corresponding Author: rashid1973@gmail.com
}

\begin{abstract}
Type 2 diabetes is associated with both extracellular and intracellular magnesium $\left(\mathrm{Mg}^{2+}\right)$ deficits. A chronic latent $\mathrm{Mg}^{2+}$ deficit or an overt clinical hypomagnesemia is common in patients with type 2 diabetes, especially in those with poorly controlled glycemic profiles. Insulin and glucose are important regulators of $\mathrm{Mg}^{2+}$ metabolism. Intracellular $\mathrm{Mg}^{2+}$ plays a key role in regulating insulin action, insulin-mediated-glucose-uptake and vascular tone. The present study was undertaken to investigate the serum and erythrocyte levels of $\mathrm{Mg}^{2+}$, and also to examine their relationship to glycemic status in a group of type 2 diabetic of Bangladeshi patients without any complications. Thirty newly diagnosed type 2 Diabetic subjects were studied with age- and BMI (body mass index)-matched Control subjects. Fasting serum glucose and fasting serum insulin level were measured by glucose oxidase method and ELISA, respectively. Total cholesterol (TChol), triglyceride, HDL and LDL in serum were measured by enzymatic colorimetric assay. Serum and erythrocyte $\mathrm{Mg}^{2+}$ levels were estimated by Ion Sensitive Electrode (ISE). There were no significant differences in anthropometric features of Control and Diabetic subjects. The lipid profile did not have any significant change except a significant increase in TChol in serum of Diabetic subjects. Fasting serum $\mathrm{Mg}^{2+}\left(\mathrm{FSMg}^{2+}\right)$ and two hours serum $\mathrm{Mg}^{2+}$ after glucose load $\left(2 \mathrm{HSMg}^{2+}\right)$ as well as fasting red blood cell $\mathrm{Mg}^{2+}\left(\mathrm{FRBCMg}^{2+}\right)$ and two hours red blood cell $\mathrm{Mg}^{2+}$ after glucose load $\left(2 \mathrm{HRBCMg}^{2+}\right)$ levels were significantly lower in Diabetic subjects. Diabetics subjects had 2.5 times more fasting serum glucose (FSG) levels. Although the fasting serum insulin (FSI) levels were similar between Control and Diabetic subjects, the insulin levels two hour after glucose load were 1.5 times more in Control subjects. The $\%$ of $\beta$ cell secretion and insulin sensitivity were significantly decreased in Diabetic subjects. There was no correlation was found between the FSG and FSI, but a significant negative correlation was observed between FSG and $\mathrm{FSMg}^{2+}$ or $\mathrm{FRBCMg}^{2+}$. These data combinedly suggest that decreased serum and intraerythrocyte magnesium could be a cause of
\end{abstract}

hyperglycemia and type 2 diabetes in Bangladeshi population.

\section{Introduction}

Magnesium ions $\left(\mathrm{Mg}^{2+}\right)$ are pivotal in the transfer, storage and utilization of energy. It is the most abundant intracellular divalent cation. The normal level of magnesium $(\mathrm{mmol} / \mathrm{L})$ in the body fluids is $0.70-1.00$ in serum/plasma, 0.5 in interstitial fluid and 13 in intracellular fluid respectively. There are two major roles of magnesium in the biological system. First, it can compete with calcium for binding sites on proteins and membranes and, secondly, it can form chelates with important intracellular anionic ligands, notably $\mathrm{ATP}^{1} . \mathrm{Mg}^{2+}$ plays an important role in glucose homeostasis, as a co-factor of many enzymes, especially those utilizing high energy phosphate bonds. Magnesium is involved on multiple levels of insulin secretion, binding and activity. Low level of $\mathrm{Mg}^{2+}$ can reduce secretion of insulin by the pancreas. $\mathrm{Mg}^{2+}$ also plays an important role in insulin action ${ }^{2} . \mathrm{Mg}^{2+}$ supplementation improves insulin sensitivity as well as insulin secretion in patients with Type 2 diabetes. In Diabetic subjects, there is a direct relationship between serum $\mathrm{Mg}^{2+}$ level and cellular glucose. This change in glucose disposal has been shown to be related to increased sensitivity of the tissues to insulin in the presence of adequate $\mathrm{Mg}^{2+}$ levels ${ }^{3}$.

$\mathrm{Mg}^{2+}$ depletion in diabetes is thought to be due to osmotic diuresis. The $\mathrm{Mg}^{2+}$ concentration of $\mathrm{RBC}$ in patients is significantly reduced compared to nondiabetic subjects. Hypomagnesemia has been reported to occur in diabetes mellitus in the course of recovery from ketoacidosis. However, it is well known that serum $\mathrm{Mg}^{2+}$ level does not accurately reflect the true state of total body $\mathrm{Mg}^{2+}$. Various studies revealed that intraerythrocytic $\mathrm{Mg}^{2+}$ concentration is a sensitive predictor of $\mathrm{Mg}^{2+}$ concentration in Diabetic patients. $\mathrm{Mg}^{2+}$ is accumulated within $\mathrm{RBC}$ in presence of glucose and insulin while glucose alone had no significant effect. Insulin stimulates the shift of $\mathrm{Mg}^{2+}$ from plasma to the $\mathrm{RBC}$ in vivo and in vitro. These in vivo and in vitro results suggest that insulin is an important modulator of intracellular $\mathrm{Mg}^{2+}$ content ${ }^{4}$. 
$\mathrm{Mg}^{2+}$ deficiency has been implicated in the pathogenesis of both macrovascular as well as microvascular complications of diabetes. A relationship between hypomagnesemia and diabetic late complications has been shown in several studies, although the mechanism is still unknown. $\mathrm{Mg}^{2+}$ deficiency also considered as an important factor, leading to cardiovascular diseases ${ }^{5}$.

The present study was designed to investigate the relative roles of intraerythrocytic $\mathrm{Mg}^{2+}$ and its relation to insulin resistance in Type 2 diabetes. Taking advantage of the high sensitivity and specificity of the Ion Sensitive Electrode (ISE) technique, the present study made a first attempt to conduct measurement of intraerythrocytic $\mathrm{Mg}^{2+}$ in Bangladeshi diabetic patients as well as in corresponding controls. Due to racial, ethnic and environmental variations in this subcontinent, the Diabetic subjects are prone to various kinds of trace element deficiency. Among the trace elements, $\mathrm{Mg}^{2+}$ possesses a prime importance in type 2 diabetes. Moreover, due to changes in food habits, wide spread illiteracy, ignorance and religious taboos, Bangladeshi population end up with inadequate consumption of $\mathrm{Mg}^{2+}$ in their diet. A good number of the Diabetic patients of this population are middle aged (40-50 years old), and they have a number of characteristics which make them suitable for such kind of investigation. They have normal to higher BMI. Many of them are free from hypertension, dyslipidemia and they do not present with ketoacidosis in spite of moderate or severe degree hyperglycemia. In this study, a group of these subjects are studied to find out the abnormal insulin secretion and insulin sensitivity and assessed by HOMA mode ${ }^{6-7}$.

In the context of availability of such a group, we undertook the study to explore the relative role of intraerythrocytic $\mathrm{Mg}^{2+}$ and insulin resistance in type-2 Diabetic patients. As there is increasing evidence that deficiency of $\mathrm{Mg}^{2+}$ within the cell is one of the important biochemical changes in the development of complications in type 2 diabetes, it is necessary to measure $\mathrm{Mg}^{2+}$ in Diabetic subjects. So, $\mathrm{Mg}^{2+}$ estimation is considered to be an essential parameter in the management of Diabetic complications because if the Diabetic subjects are hypomagnesemic then $\mathrm{Mg}^{2+}$ supplementation could prevent further complications. Although the present investigation has covered only a section of Control and Diabetic subjects in Bangladeshi population, we hope that it will provide an important methodological and technical standardization for further studies in this area.

\section{Materials and Methods}

Thirty newly diagnosed type 2 Diabetic subjects (age in years $46.30 \pm 2.41$; BMI $27.26 \pm 1.60, \mathrm{M} \pm \mathrm{SD}$ ) were studied with thirty age- and BMI- matched Control subjects (age $45.17 \pm 2.79$; BMI $26.50 \pm 1.79$ ). Serum glucose was measured by glucose oxidase method. Total serum cholesterol, serum triglyceride and serum HDL and LDL were measured by enzymatic colorimetric assay. Fasting serum insulin levels were measured by ELISA. Serum and red blood cell $\mathrm{Mg}^{2+}$ levels were estimated by Ion Sensitive Electrode (ISE) method by using Nova 8 Auto-analyzer.

\section{General principle of collection and preservation of samples}

On the date of appointment, fasting and 2 hours blood samples after $75 \mathrm{gm}$ oral glucose load were collected in glass test tubes. Ordinary glass syringes were not used to avoid environmental contamination. Blood samples were kept in capped, air tight glass test tubes. Prior to sample collection the containers and test tubes were washed with proper aseptic precautions in the following manner: (a) The container and test tubes were washed with detergent. (b) Those were then soaked in $1: 1(\mathrm{~V} / \mathrm{V})$ nitric acid (70\%) for 2 to 3 days. (c) Those were rinsed with double distilled deionized water and then dried in an oven at $60^{\circ} \mathrm{C}$. The test tubes were sealed with parafilm. Serum was separated by centrifugation at $2000 \mathrm{rpm}$ for $10 \mathrm{~min}$ at $20^{\circ} \mathrm{C}$ immediately after the blood was allowed to clot for 30 minutes. Separated serum was aliquoted and preserved immediately at $-80^{\circ} \mathrm{C}$ for the future estimation of serum glucose and insulin, lipid contents and serum magnesium.

\section{Preparation of red blood cell (erythrocytes)}

For determination of red blood cell magnesium, blood was taken in a heparinized acid washed test tube and then erythrocytes were separated from plasma. Blood samples were centrifuged at $3000 \mathrm{rpm}$ for 15 minutes at $4^{0} \mathrm{C}$. Supernatant was withdrawn including buffy coat with sucker machine. The cells were washed with ice cold sucrose solution $(300 \mathrm{mM})$ for three times to get rid of extracellular $\mathrm{Mg}^{2+}$. Cells were lysed by Titron-X 100 and vortex. Then, the samples were suspended in a buffer solution containing $200 \mathrm{mM}$ $\mathrm{NaCl}, 1 \mathrm{mM} \mathrm{MgCl} 2$ and $1 \mathrm{mM} \mathrm{CaCl} 2$ and the deionized water was added followed by the estimation of intraerythrocyte magnesium by ISE method by using Nova-8 Auto-analyzer.

\section{Statistical Analysis}

Details of medical history and clinical findings of the subjects were recorded in a redesigned case record form. All analyses were done using the SPSS (Statistical package for social science) software for windows. Experimental values were expressed as mean SD (standard deviation) or median (range) where 
ever appropriate. To compare results between two groups unpaired students t-test, Mann-Whitney and Wilcoxan-Ranksum tests were used. For the same group, paired students t-test was performed. Pearson correlation coefficient was done to show the correlation between different parameters in the same group. Statistical significance was considerable to be indicated by a $\mathrm{P}$ value of less than 0.05 in all cases.

Table 1: Clinical and anthropometric features of the study subjects

\begin{tabular}{|l|c|c|c|c|c|c|}
\hline \multicolumn{1}{|c|}{ Groups } & $\begin{array}{c}\text { Age } \\
(\text { Years })\end{array}$ & $\begin{array}{c}\text { BMI } \\
\left(\mathrm{Kg} / \mathrm{m}^{2}\right)\end{array}$ & STR & WHR & $\begin{array}{c}\text { SBP } \\
(\mathrm{mmHg})\end{array}$ & $\begin{array}{c}\text { DBP } \\
(\mathrm{mmHg})\end{array}$ \\
\hline $\begin{array}{l}\text { Control } \\
(\mathrm{n}=30)\end{array}$ & $45.17 \pm 2.79$ & $26.50 \pm 1.79$ & $1.86 \pm 0.30$ & $0.93 \pm 0.02$ & $122.83 \pm 5.20$ & $79.33 \pm 4.30$ \\
\hline $\begin{array}{l}\text { Diabetic } \\
(\mathrm{n}=30)\end{array}$ & $46.30 \pm 2.41$ & $27.26 \pm 1.60$ & $1.95 \pm 0.36$ & $0.94 \pm 0.03$ & $127.17 \pm 5.97$ & $79.33 \pm 4.57$ \\
\hline $\mathbf{t} / \mathbf{p}$ Values \\
\hline Con vs Diab & $-3.61 / 0.038$ & $-1.73 / 0.089$ & -0.9410 .350 & $-0.90 / 0.037$ & $-2.99 / 0.004$ & $0.001 / 1.000$ \\
\hline
\end{tabular}

Results are expressed as mean \pm SD. $\mathrm{n}=$ number of study subjects. Comparisons between groups were done by unpaired student's t-test. BMI, Body mass index; STR, Subscapular triceps ratio; WHR, Waist hip ratio; SBP, Systolic blood pressure; DBP, Diastolic blood pressure; Con, Control; Diab, Diabetic.

\section{Results}

\section{Measurement of Anthropometric Parameters}

The data of presented in Table 1 showed that the anthropometric parameters of both groups (Control vs Diabetic) were similar. The differences in age of the two study groups were almost similar (Control: $45.17 \pm 1.66$ vs Diabetic $46.30 \pm 2.41$ years). The BMI of the two groups were also matched (Control:
$26.50 \pm 1.79$ vs Diabetic $27.26 \pm 1.60 \mathrm{Kg} / \mathrm{m}^{2}$ ). The groups also had similar systolic and diastolic blood pressure (Control: $122.83 \pm 5.20$ and $79.33 \pm 4.30$ vs Diabetic: $127.17 \pm 5.97$ and $79.33 \pm 4.50)$. The subscapular-triceps, STR, (Control: $1.86 \pm 0.30$ vs Diabetic: $1.95 \pm 0.36$ ) and waist hip ratio, WHR, (Control: $0.93 \pm 0.02$ vs Diabetic: $0.94 \pm 0.03$ ) of two groups were also similar.

Table 2: Lipid profile of different groups of the study subjects

\begin{tabular}{|l|c|c|c|c|}
\hline \multicolumn{1}{|c|}{ Groups } & $\begin{array}{c}\text { TChol } \\
(\mathrm{mg} / \mathrm{dl})\end{array}$ & $\begin{array}{c}\text { TG } \\
(\mathrm{mg} / \mathrm{dl})\end{array}$ & $\begin{array}{c}\text { HDLChol } \\
(\mathrm{mg} / \mathrm{dl})\end{array}$ & $\begin{array}{c}\text { LDLChol } \\
(\mathrm{mg} / \mathrm{dl})\end{array}$ \\
\hline $\begin{array}{l}\text { Control } \\
(\mathrm{n}=30)\end{array}$ & $180.60 \pm 23.61$ & $166.73 \pm 44.32$ & $32.67 \pm 5.19$ & $114.59 \pm 23.54$ \\
\hline $\begin{array}{l}\text { Diabetic } \\
(\mathrm{n}=30)\end{array}$ & $196 \pm 15.97$ & $180 \pm 41.81$ & $33.67 \pm 5.23$ & $126.33 \pm 13.86$ \\
\hline t/p Values & \multicolumn{5}{|l|}{} \\
\hline Con vs Diab & $-2.96 / 0.004$ & $-1.19 / 0.238$ & $-0.743 / 0.460$ & $-2.36 / 0.023$ \\
\hline
\end{tabular}

Results are expressed as mean \pm SD. $n=$ numbers of subjects. Comparisons between the groups were done by unpaired student's t test. TChol, Total cholesterol; TG, Triglyceride; HDLChol, High density lipoprotein cholesterol; LDLChol, Low density lipoprotein cholesterol; Con, Control; Diab, Diabetic.

\section{Examination of Lipid Profile}

To examine the lipid profile of the Control and Diabetic subjects, we measured total cholesterol (TChol), triglyceride (TG), high density lipoprotein cholesterol (HDLChol) and low density lipoprotein cholesterol (LDLChol). The data suggested that except the TChol, the Diabetic subjects had similar lipid profile compared to Control subjects as shown in Table 2. However, the TChol in serum was significantly higher in the Diabetic subjects compared to Control subjects (Control: 180.60 \pm 23.61 vs Diabetic: $196 \pm 15.97, \mathrm{p}<0.004)$. 
Estimation of serum and $\mathrm{RBC} \mathrm{Mg}^{2+}$ concentration Next, we determined the $\mathrm{Mg}^{2+}$ levels in serum of Controls and Diabetic subjects after fasting and two hours glucose load. Fasting serum $\mathrm{Mg}^{2+}\left(\mathrm{FSMg}^{2+}\right)$ and
$2 \mathrm{HSMg}^{2+}$ is significantly lowered than $\mathrm{FSMg}^{2+}$ $(\mathrm{p}<0.001)$ in Diabetic subjects. Further, we estimated the red blood cell $\mathrm{Mg}^{2+}$ in serum of Controls and Diabetic subjects after fasting and two hours glucose

Table 3: Serum and RBC Magnesium of different groups of the study subjects

\begin{tabular}{|c|c|c|c|c|c|c|}
\hline \multirow[t]{2}{*}{ Groups } & \multirow[t]{2}{*}{ FSMg $^{2+}$} & \multirow[t]{2}{*}{$2 \mathrm{HSMg}^{2+}$} & \multirow[t]{2}{*}{$\mathrm{FRBCMg}^{2+}$} & \multirow[t]{2}{*}{ 2HRBCMg ${ }^{2+}$} & \multicolumn{2}{|c|}{ Paired t-test ( $\mathrm{t} / \mathrm{p}$ values) } \\
\hline & & & & & $\begin{array}{c}\mathrm{FSMg}^{2+} \\
\& \\
2 \mathrm{HSMg}^{2+}\end{array}$ & $\begin{array}{c}\text { FRBCMg }^{2+} \\
\& \\
2 \mathrm{HRBCMg}^{2+}\end{array}$ \\
\hline $\begin{array}{l}\text { Control } \\
(\mathrm{n}=30)\end{array}$ & $0.47 \pm .02$ & $0.48 \pm .03$ & $1.82 \pm 0.23$ & $1.73 \pm 0.18$ & $-1.18 / .246$ & $2.60 / .014$ \\
\hline $\begin{array}{l}\text { Diabetic } \\
(n=30)\end{array}$ & $0.44 \pm .03$ & $0.42 \pm .02$ & $1.75 \pm 0.21$ & $1.56 \pm 0.19$ & $6.89 / .001$ & $11.44 / .001$ \\
\hline \multicolumn{5}{|l|}{ t/p Values } & & \\
\hline Con vs Diab & $4.04 / .001$ & $7.94 / .001$ & $1.26 / .213$ & $3.52 / .001$ & & \\
\hline
\end{tabular}

Results are expressed as mean \pm SD. $n=$ numbers of subjects. Comparisons between groups were done by unpaired student's t-test. FSMg ${ }^{2+}$, Fasting serum magnesium; $2 \mathrm{HSMg}$, 2 hours serum magnesium; FRBCMg, Fasting red blood cell magnesium; 2HRBC, 2 hours red blood cell magnesium. Con, Control; Diab, Diabetic.

Table 4a: Glycemic status, Serum insulin levels of the study subjects

\begin{tabular}{|c|c|c|c|c|c|c|}
\hline Groups & FSG & 2HSG & FSI & 2HSI & \multicolumn{2}{|c|}{ Paired t-test ( $\mathrm{t} / \mathrm{p}$ values) } \\
\hline & & & & & $\begin{array}{c}\text { FSG } \\
\& \\
\text { 2HSG }\end{array}$ & $\begin{array}{c}\text { FSI } \\
\& \\
\text { 2HSI }\end{array}$ \\
\hline $\begin{array}{l}\text { Control } \\
(\mathrm{n}=30)\end{array}$ & $4.72 \pm 0.5$ & $6.15 \pm 0.5$ & $\begin{array}{l}73.84 \\
(42.60-152.65)\end{array}$ & $\begin{array}{l}483.15 \\
(151.94-1341.90)\end{array}$ & $-27.20 / 0.001$ & $-8.86 / 0.001$ \\
\hline $\begin{array}{l}\text { Diabetic } \\
(n=30)\end{array}$ & $10.14 \pm 1.7$ & $15.33 \pm 2.1$ & $\begin{array}{l}69.94 \\
(22.72-124.96)\end{array}$ & $\begin{array}{l}272.29 \\
(42.60-482.80)\end{array}$ & $-12.52 / 0.001$ & $-7.51 / 0.001$ \\
\hline \multicolumn{5}{|c|}{ u/p values } & & \\
\hline Con vs Diab & $16.40 / 0.001$ & $23.18 / .001$ & $399.0 / 0.451$ & $134.0 / 0.001$ & & \\
\hline
\end{tabular}

two hours serum $\mathrm{Mg}^{2+}$ after glucose load $\left(2 \mathrm{HSMg}^{2+}\right)$ levels were significantly lower in the Diabetic compared to Control subjects (Control: $0.47 \pm 0.02$ $\left(\mathrm{FSMg}^{2+}\right)$ and $0.48 \pm 0.03\left(2 \mathrm{HSMg}^{2+}\right)$ vs Diabetic: $0.44 \pm 0.03 \quad\left(\mathrm{FSMg}^{2+}\right)$ and $0.42 \pm 0.02 \quad\left(2 \mathrm{HSMg}^{2+}\right)$ $\mathrm{mmol} / \mathrm{L}, \mathrm{p}<0.001)$. When compared within the groups load. Both fasting red blood cell $\mathrm{Mg}^{2+}\left(\mathrm{FRBCMg}^{2+}\right)$ and two hours red blood cell $\mathrm{Mg}^{2+}$ after glucose load $\left(2 \mathrm{HRBCMg}^{2+}\right)$ were also significantly lower in Diabetic subjects compared to Control subjects (Control: $1.82 \pm 0.23 \quad\left(\mathrm{FRBCMg}^{2+}\right)$ and $1.73 \pm 0.18$ $\left(2 \mathrm{HRBCMg}^{2+}\right) \mathrm{mmol} / \mathrm{L}$ vs Diabetic: $1.75 \pm 0.21$ 
$\left(\mathrm{FRBCMg}^{2+}\right)$ and $1.56 \pm 0.19\left(2 \mathrm{HRBCMg}^{2+}\right) \mathrm{mmol} / \mathrm{L}$ $(\mathrm{p}<0.001)$. The $\mathrm{Mg}^{2+}$ levels in $2 \mathrm{HRBCMg}^{2+}$ group were lower than $\mathrm{FRBCMg}^{2+}$ group in Diabetic subjects as well as in Control subjects, $\mathrm{p}<0.01$ (Table 3).

\section{Glycemic status, insulin secretion and sensitivity}

In this experiment, we evaluated glycemic status in Controls and diabetic subjects. The glycemic value of Diabetic subjects showed 2.5 times higher fasting serum glucose (FSG) level compared to the Control subjects (Control: $4.72 \pm 0.50$ vs Diabetic: $10.14 \pm 1.74$, $\mathrm{mmol} / \mathrm{L}, \mathrm{p}<0.001)$. The fasting serum insulin (FSI) levels were similar in both the subjects (Control: 73.84 (range, 42.60-152.65) and Diabetic: 69.94 (range,
22.72-124.96) $\mathrm{mmol} / \mathrm{L}$. However, the insulin levels two hours after glucose load were $\sim 1.5$ times lower in Diabetic compared to Control subjects (Controls: 474.99 (range, 151.94-1618.80) and Diabetic: 272.29 (42.60-493.45) $\mathrm{mmol} / \mathrm{L}, \quad \mathrm{p}<0.001) \quad$ (Table 4a). In another experiment, we assessed insulin secretion and insulin sensitivity using Homeostasis Model Assessment (HOMA). The HOMA \% $\beta$ ( $\beta$-cell insulin secretion, $\mathrm{p}<0.001$ ) and HOMA $\% \mathrm{~S}$ (insulin sensitivity, $\mathrm{p}<0.05)$ were significantly impaired in Diabetic subjects compared to Control subjects (Table 4b).

Table 4b: B cell functions (HOMA \% $\boldsymbol{\beta}$ ) and insulin sensitivity (HOMA \% S) of the study subjects

\begin{tabular}{|l|c|c|}
\hline \multicolumn{1}{|c|}{ Groups } & HOMA \% $\beta$ & HOMA \% S \\
\hline $\begin{array}{l}\text { Control } \\
(\mathrm{n}=30)\end{array}$ & $\begin{array}{c}121.95 \\
(22.70-224.30)\end{array}$ & $\begin{array}{c}75.37 \\
(57.10-223.00)\end{array}$ \\
\hline $\begin{array}{l}\text { Diabetic } \\
(\mathrm{n}=30)\end{array}$ & $\begin{array}{c}28.15 \\
(11.20-65.00)\end{array}$ & $\begin{array}{c}66.0 \\
(21.30-97.40)\end{array}$ \\
\hline $\begin{array}{l}\text { u/p values } \\
\text { Con vs Diab }\end{array}$ & $19.00 / 0.001$ & $287.50 / 0.02$ \\
\hline
\end{tabular}

Results are expressed as Mean (Range). $\mathrm{n}=$ numbers of subjects. Comparisons between the groups were done by

Mann-Whitney Wilcoxan Ranksum test. HOMA, Homeostasis Model Assessment. Con, Control; Diab, Diabetic.

Table 5: Pearson correlation study between fasting serum glucose and fasting serum insulin, fasting serum magnesium, red blood cell magnesium of the study subjects.

\begin{tabular}{|l|c|c|c|c|c|c|}
\hline \multicolumn{1}{|c|}{ FSG vs } & \multicolumn{2}{|c|}{ FSI } & \multicolumn{2}{c|}{ FSMg $^{2+}$} & \multicolumn{2}{c|}{ FRBCMg $^{2+}$} \\
\hline Groups & r & p & r & p & r & p \\
\hline $\begin{array}{l}\text { Control } \\
(\mathrm{n}=30)\end{array}$ & 0.08 & 0.643 & 0.115 & 0.546 & 0.201 & 0.288 \\
\hline $\begin{array}{l}\text { Diabetic } \\
(\mathrm{n}=30)\end{array}$ & 0.07 & 0.710 & -0.887 & 0.001 & -0.883 & 0.001 \\
\hline
\end{tabular}

FSG, Fasting serum glucose; FSI, Fasting serum insulin, $\mathrm{FSMg}^{2+}$, Fasting serum magnesium; $\mathrm{FRBCMg}^{2+}$, Fasting red blood cell magnesium. 
We also assessed the correlation between FSG and FSI or $\mathrm{FSMg}^{2+}$ and $\mathrm{FRBCMg}^{2+}$. FSG in both the Control and Diabetic subjects did not correlate with FSI. A significant negative correlation was observed in Diabetes subjects between FSG and $\mathrm{FSMg}^{2+}(\mathrm{r}=$ $0.887, \mathrm{p}=0.001)$ or $\mathrm{FRBCMg}^{2+}(\mathrm{r}=-0.883, \mathrm{p}=0.001)$. No correlation was observed in case of Control subjects (Table 5).

\section{Discussion}

In general, $\mathrm{Mg}^{2+}$ participates in a wide array of cellular processes that also critical to both glucose and insulin metabolism. Although the role of $\mathrm{Mg}^{2+}$ in the various metabolic processes of the body is well established, a mutual understanding on precise balance of this element, particularly within the cell, of the Diabetic patients in relation to glucose homeostasis and insulin action have not yet been attained yet. One of the major reasons for this controversy is the dissimilar response of the extracellular and intracellular fluid compartments in a magnesium deficient state. It has been claimed that erythrocyte $\mathrm{Mg}^{2+}$ levels could reflect total $\mathrm{Mg}^{2+}$ more accurately than that of serum level.

Decrease in $\mathrm{Mg}^{2+}$ levels in serum has been reported earlier in the Bangladeshi Diabetic population ${ }^{13,8}$. However, the analysis of $\mathrm{Mg}^{2+}$ levels in serum and erythrocyte using ISE based Auto-analyzer method for a comprehensive estimation is the first attempt in this study. The relatively large number of elderly Diabetic patients in Bangladesh, who do not have ketoacidosis in spite of moderate to severe degree of hyperglycemia, they are free from dyslipidemia and hypertension that provide a unique model for such studies.

We have described a group of newly diagnosed Diabetic subjects with mean body weight of $27.26 \pm 1.60 \mathrm{Kg}$ (Table 1) who have blood pressure and serum lipid levels within the normal range. Other anthropometric parameters like STR and WHR are also within normal limits. We could get a Control subjects with all parameters matched except TChol in serum that has slightly higher levels in the Diabetic subjects.

The serum and red blood cell $\mathrm{Mg}^{2+}$ levels in Control subjects have been found to have mean value of $0.47 \pm 0.02\left(\mathrm{FSMg}^{2+}\right)$ and $1.82 \pm 0.23\left(\mathrm{FRBCMg}^{2+}\right)$ $\mathrm{mmol} / \mathrm{L}$ in Control subjects (Table 3). It can be seen that the mean value, which is observed in Bangladeshi type 2 Diabetic subjects, is substantially below the corresponding (normal) values $0.94 \pm 0.07\left(\mathrm{FSMg}^{2+}\right)$ and $2.29 \pm 0.56 \quad\left(\mathrm{FRBCMg}^{2+}\right) \quad \mathrm{mmol} / \mathrm{L}$ among Johannesburg urbanized population ${ }^{8,9}$. This difference is probably due to the application of different methods of $\mathrm{Mg}^{2+}$ measurement in the studies i.e., ISE in the former and Atomic Absorption Spectrophotometry in the latter. As compared to Control subjects, the
Diabetic subjects have reduced value of $\mathrm{Mg}^{2+}$ both in $\mathrm{FSMg}^{2+}(0.44 \pm 0.03)$ and $2 \mathrm{HSMg}^{2+}(0.42 \pm 0.02)$ $\mathrm{mmol} / \mathrm{L}$, and $\mathrm{FRBCMg}^{2+}(1.75 \pm 0.21)$ and $2 \mathrm{HRBCMg}^{2+}(1.56 \pm 0.19) \mathrm{mmol} / \mathrm{L}$ (Table 3$)$. It is clear from the above data that $\mathrm{Mg}^{2+}$ concentrations (both fasting and $2 \mathrm{~h}$ after oral glucose load) in the Controls subjects do not vary and the $\mathrm{Mg}^{2+}$ homeostasis is well maintained by the intact insulin secretion. In contrast, significantly low values of both serum and intracellular $\mathrm{Mg}^{2+}$ after $2 \mathrm{~h}$ of glucose load in comparison to that of fasting levels have indicated that the accelerated excretion of $\mathrm{Mg}^{2+}$ could happen through the renal tubules.

A major controversy in the $\mathrm{Mg}^{2+}$ homeostasis in Diabetic patients is the distribution of the $\mathrm{Mg}^{2+}$ in extracellular and intracellular compartments, particularly in response to glucose. Some authors suggest that there occurs a sequestration of magnesium in the cytoplasm in response to hyperglycemia, which consequently results in hypomagnesemia ${ }^{9,10}$. If this hypothesis is true, a lower value of $\mathrm{Mg}^{2+}$ in erythrocytes is expected in Diabetic subjects. On the other hand, insulin induces entrance of $\mathrm{Mg}^{2+}$ into the cells (e.g., RBC) with consequent reduction of plasma $\mathrm{Mg}^{2+}$ independent of insulin. Glucose load alone can suppress the intracellular $\mathrm{Mg}^{2+}$ with minor elevation of serum $\mathrm{Mg}^{2+10,11}$. Thus, in Diabetic subjects with relative insulin deficiency, low erythrocyte and plasma $\mathrm{Mg}^{2+}$ concentration could develop due to two reasons: firstly, due to poor gastrointestinal uptake and secondly, due to accelerated renal tubular excretion, which results from osmotic diuresis (glucose acts as an osmotically active substance). This, however, does not exclude the fact that extracellular $\mathrm{Mg}^{2+}$ turnover could increase with no net increase in the intracellular $\mathrm{Mg}^{2+}$.

The imbalance of $\mathrm{Mg}^{2+}$ homeostasis can reflect the depressed activity of Na-K-ATPase pump as postulated by others. Change in membrane fluidity could complicate the normal transport of ions across the cell membrane. On the contrary, ATPase activity of erythrocyte membrane has been shown to decease significantly in Diabetic patients ${ }^{11,12}$. It is conceivable that biochemical alterations occur in diabetic patients at the level of cation transport systems of the membrane. The factors responsible for the reduced enzyme activity are elusive. However, the available evidence suggests that the altered physical state of the lipid moiety of diabetic membrane may constitute a plausible molecular basis for Na-K-ATPase dysfunction. Since the Na-K-ATPase activities are critically dependent on the composition and fluidity of the surrounding phospholipid bilayer, the alteration observed in diabetic membranes are most likely accompanied by a reduced enzyme activity. ${ }^{11-13}$ So the membrane change in the red blood cell of Diabetic subjects could contribute to the alteration of ion across 
Cell membrane. The $\mathrm{Mg}^{2+}$ contents of the erythrocytes, to a certain extent, reflect those of the other cells of the organism. Fluctuation in the $\mathrm{Mg}^{2+}$ contents of the erythrocyte could be an indicator of unstable intracellular $\mathrm{Mg}^{2+}$ turnover in the Diabetic subjects because of either glucose dysregulation or rather insulin deficiency. It is established that hypomagnesemia can influence the chemical events responsible for long term type 2 diabetic complications $^{5,14-16}$. Moreover, as assumed by others ${ }^{17-}$ 18, the intracellular $\mathrm{Mg}^{2+}$ levels, which reflect the insulin effects, have also be taken into consideration in the management of type 2 diabetic patients, who undergo insulin treatment.

\section{Conclusion}

This is the first study in Bangladeshi type 2 Diabetic subjects to estimate the serum and intraerythrocytic $\mathrm{Mg}^{2+}$ levels by ISE method. Thus, the results suggest the following conclusions: (a) In non-diabetic middleaged Bangladeshi population, compared to the reference in Johannesburg population, the value of serum and intraerythrocytic $\mathrm{Mg}^{2+}$ is marginally below the range, (b) lower levels of $\mathrm{Mg}^{2+}$ in serum as well as in intraerythrocytic are found in type 2 Diabetic subjects, that is caused by hyperglycemia, (c) the change in serum $\mathrm{Mg}^{2+}$ concentration may not change its concentration within the erythrocytes. However, increased turnover of $\mathrm{Mg}^{2+}$ within the erythrocytes cannot be ruled out, (d) both insulin secretion and insulin sensitivity are decreased in type 2 Diabetic subjects, (e) there is no relationship between insulin secretory function or insulin sensitivity and $\mathrm{Mg}^{2+}$ concentrations in the Diabetic subjects of Bangladeshi population. Further in-depth study using ISE-based technique is required to explore the role of $\mathrm{Mg}^{2+}$ in the pathophysiology of type 2 diabetes in association with glucose homeostasis and insulin action in Bangladeshi population.

\section{Conflict of Interest}

None

\section{References}

1. Sasaki S, et al., Kambe M: Magnesium status in patients with cardio vascular diseases. 1999, Rinsho Byori; 47: 396-401.

2. Ivandic A, et al., Cetina N: Magnesium and Potassium concentrations in insulin treated diabetic patients as related to residual insulin secretion. 1988, Diab. Croat 17:177-183.

3. Tossiello L: Hypomagnesemia and Diabetes mellitus. 1996, Arch Intern Med 156:1143-48.

4. Pickup JC, et al., Viberti GC: Hypomagnesaema in IDDM patients with microauminuria and clinical proteinuria. 1994, Diabetologia 37: 639-40.
5. Reinhart RA: Clinical correlates of the molecular and cellular actions of magnesium on the cardiovascular system. 1991, Am Heart J 121:1513.

6. Emato M, et al., Morii H: Homeostasis model assessment as a clinical index of insulin resistance in type 2 diabetic patients treated with sulfonylureas. 1999, Diabetes Care 22:818-22.

7. Mathews DR, et al., Turner RC; Homeostasis model assessment: Insulin resistance and B cell function from fasting plasma glucose and insulin concentration in man. 1985, Diabetologia 28:412-9.

8. Khan LA, et al., Khan AK: Serum and urinary magnesium in young diabetic subjects in Bangladesh. 1998, Am J Clin Nutr 69:70-3.

9. Touyz RM, et al., Reinach SG: Magnesium, calcium and potassium status in normotensive and hypertensive Johannesburg residence. 1987, S Afr Med J 72:377-81.

10. Sattar S, et al., Khan AK: Magnesium sequestration in $\mathrm{RBC}$ as a mechanism of hypomagnesium in diabetic patient. (Abstract) 1999, Diabetologia 42 (Supplementary 1):A154.

11. Resnick LM, et al., Laragh JH: Ionic basis of hypertension in Diabetes mellitus: role of hyperglycemia. 1993, Am J Hypertens 6:413-17.

12. Finotti P, Palatini P: Reduction of erythocyte $\left(\mathrm{Na}^{+}-\right.$ $\mathrm{K}^{+}$) ATPase activity in type I (insulin dependent) diabetic subjects and its activation by homologous plasma. 1986, Diabetalogia 29:623-28.

13. Fujii S, et al., Okuda K. Magnesium levels in plasma, erythrocyte and urine in patients with Diabetes mellitus 1982, Horm Metab Res 14:161-2.

14. Brown DF, et al., Doyle JT: Magnesium lipid relations in healthy and in patients with myocardial infarction. 1958, Lancet 2: 933.

15. Hyatt KH, et al., Oscherwitj M. Relationship of serum magnesium levels to serum cholesterol and triglyceride levels and to myocardial infarction. 1966, Appl Spectros 20:142.

16. Zhou Q, et al., Kummerow FA: Cholesterol metabolism in human umbilical arterial endothelial cells cultured in low magnesium media. 1997, Magnes Res 10:355-60.

17. American Diabetes Association: Magnesium supplementation in the treatment of Diabetes. 1992, Diabetes Care 15:1065-67.

18. Lima MDL, et al., Conguca V. The effect of magnesium supplementation in increasing doses on the control of type 2 diabetes. 1998, Diabetes Care 21:682-86. 